\title{
Peningkatan Keterampilan Berbahasa melalui Teknik Reportase Mahasiswa Program Studi Komunikasi dan Penyiaran Islam (KPI) IAIN Syaikh Abdurrahman Siddik Bangka Belitung
}

\author{
Eva Harista \\ IAIN Syaikh Abdurrahman Siddik Bangka Belitung, Indonesia \\ harista.eva@gmail.com
}

\begin{abstract}
This study aims to improve language skills (listening, reading, speaking, and writing) KPI Study Program students Semester VI 2017/2018 Academic Year, Da'wah and Communication Department, IAIN Syaikh Abdurrahman Siddik Bangka Belitung through reportage techniques. This type of research is classroom action research (CAR). The design in PTK consists of three cycles in which there are four components in each cycle, namely planning, implementing actions, results of actions, and reflection. In this CAR, researchers used the Elliot model with modifications. This research is the result of learning from the Indonesian Language Discourse course for KPI. The subjects in this study were the sixth semester students of the Islamic Communication and Broadcasting Study Program (KPI) totaling 9 students. The results showed that in the first cycle, the average grade was 74.66 with a fairly good category. In cycle II students' language skills experienced a slight increase. This can be seen from the average grade, which is increased to 79.66 with a good enough category. The increase in the average grade from cycle I to cycle II is 5.00. In cycle III there was a significant increase with 85.77 class average value. Language skills in cycle III can be categorized as good. As for increasing the average grade from cycle II to cycle III, which is 6.11 .
\end{abstract}

Keywords; Language Skills, Students, Reporting Techniques.

Abstrak:
Penelitian ini bertujuan untuk meningkatkan keterampilan berbahasa (menyimak, membaca,
berbicara, dan menulis) mahasiswa Program Studi Komunikasi dan Penyiaran Islam Semester
VI Tahun Akademik 2017/2018, Jurusan Dakwah dan Komunikasi, IAIN Syaikh Abdurrahman
Siddik Bangka Belitung melalui teknik reportase. Jenis penelitian ini adalah penelitian
tindakan kelas (PTK). Rancangan dalam PTK terdiri dari tiga siklus yang mana dalam setiap
siklusnya terdapat empat komponen, yaitu perencanaan, pelaksanaan tindakan, hasil
tindakan, dan refleksi. Dalam PTK ini peneliti menggunakan model Elliot dengan modifikasi.
Penelitian ini merupakan hasil pembelajaran dari mata kuliah Wacana Bahasa Indonesia
untuk KPI. Adapun subjek dalam penelitian ini adalah mahasiswa Semester VI Program Studi
Komunikasi dan Penyiaran Islam (KPI) yang berjumlah 9 orang mahasiswa. Hasil penelitian
menunjukkan bahwa pada siklus I, nilai rata-rata perkelas diperoleh 74,66 dengan kategori
cukup baik. Pada siklus II keterampilan berbahasa mahasiswa mengalami sedikit
peningkatan. Hal ini terlihat dari nilai rata-rata kelas yaitu meningkat menjadi 79,66 dengan
kategori cukup baik. Adapun peningkatan nilai rata-rata kelas dari siklus I ke siklus II yaitu
5,00. Pada siklus III terjadi peningkatan yang cukup signifikan dengan nilai rata-rata kelas
85,77. Keterampilan berbahasa pada siklus III dapat dikategorikan baik. Adapun peningkatan
nilai rata-rata kelas dari siklus II ke siklus III yaitu sebesar 6,11.

Keywords; Keterampilan Berbahasa, Mahasiswa, Teknik Reportase.

Received: 7-04-2018; accepted: 18-06-2018; published: 30-06-2018

Citation: Eva Harista, 'Peningkatan Keterampilan Berbahasa melalui Teknik Reportase Mahasiswa Program Studi Komunikasi dan Penyiaran Islam (KPI) IAIN Syaikh Abdurrahman Siddik Bangka Belitung', Mawa'izh, vol. 9, no. 1 (2018), pp. 40-56. 


\section{A. Pendahuluan}

eterampilan berbahasa mutlak dimiliki oleh setiap mahasiswa, terutama
mahasiswa Program Studi Komunikasi dan Penyiaran Islam (KPI) Jurusan
Dakwah dan Komunikasi. Mahasiswa Prodi KPI harus unggul dalam setiap aspek keterampilan berbahasa tersebut. Hal ini dikarenakan mahasiswa Program Studi KPI memang berkecimpung dalam bidang ilmu komunikasi dan penyiaran. Tentunya, bidang tersebut tidak terlepas dari aspek kebahasaan yang menjadi modal utama yang nantinya akan mendukung mereka menjalani bidang tersebut.

Keterampilan berbahasa itu meliputi keterampilan menyimak/mendengarkan (listening skills), keterampilan berbicara (speaking skills), keterampilan membaca (reading skills), dan keterampilan menulis (writing skills). Keterampilan berbahasa dapat digolongkan ke dalam dua kategori yaitu kategori reseptif dan kategori produktif. Keterampilan berbahasa kategori reseptif yaitu keterampilan menyimak dan membaca. Keterampilan ini bersifat penerimaan atau penyerapan. Sedangkan keterampilan berbahasa kategori produktif yaitu keterampilan berbicara dan menulis. Keterampilan ini bersifat pengeluaran atau pemproduksian bahasa baik yang dilakukan secara lisan maupun tertulis. Menurut Mafrukhi, ${ }^{1}$ keempat keterampilan berbahasa ini saling berkaitan satu sama lain, sehingga untuk mempelajari salah satu keterampilan berbahasa, beberapa keterampilan berbahasa lainnya juga akan terlibat.

Salah satu mata kuliah di Program Studi KPI yang akan menunjang aspek kebahasaan adalah mata kuliah Wacana Bahasa Indonesia untuk KPI. Dalam mata kuliah ini, untuk mengembangkan aspek keterampilan menyimak, keterampilan berbicara, keterampilan membaca, dan keterampilan menulis secara optimal, dosen memberikan materi reportase.

Reportase adalah kegiatan liputan jurnalistik dalam rangka mengumpulan datadata dari berbagai sumber untuk dijadikan sebuah berita, yang disampaikan secara langsung di tempat kejadian. Seseorang yang melakukan reportase disebut sebagai reporter. Melalui reporter inilah, penyampaian berita akan disampaikan secara lisan dan dapat disaksikan/didengarkan khalayak secara langsung baik itu melalui radio maupun televisi.

\footnotetext{
${ }^{1}$ Mafrukhi, et al., Bagaimana Meningkatkan Kemampuan Membaca (Jakarta: Erlangga, 2007), p. 31.
} 
Pada mata kuliah wacana bahasa Indonesia untuk KPI, mahasiswa terlibat langsung dalam proses reportase. Di awal praktik reportase, dosen sekaligus peneliti memberikan tugas kepada mahasiswa untuk membuat teks berita reportase secara tertulis yang dilakukan perindividu. Setelah diberikan waktu 15 menit, mahasiswa mempraktikkan hasil reportase tersebut di depan kelas secara lisan.

Dari hasil observasi yang peneliti lakukan di awal pembelajaran, ada beberapa mahasiswa Program Studi KPI kurang terampil dalam berbahasa lisan maupun tulisan. Hal ini terlihat ketika dilakukan praktik awal reportase, mayoritas mahasiswa kebingungan dalam merangkai kata-kata, sehingga banyak terdapat kalimat yang tidak efektif.

Melalui permasalahan inilah, dosen sekaligus peneliti ingin meningkatkan keterampilan berbahasa (menyimak, membaca, berbicara, dan menulis) mahasiswa Program Studi KPI Semester VI Tahun Akademik 2017/2018 Jurusan Dakwah dan Komunikasi IAIN Syaikh Abdurrahman Siddik Bangka Belitung melalui teknik reportase. Hal ini penting dilakukan karena output dari Program Studi KPI salah satunya bisa menjalani bidang profesi sebagai seorang reporter.

\section{B. Keterampilan Berbahasa}

Keterampilan berbahasa mencakup empat komponen. Keempat komponen tersebut yaitu menyimak, berbicara, membaca, dan menulis. Dalam kegiatan menulis dan berbicara, seseorang memerlukan sebuah ide, inspirasi, dan informasi untuk mengembangkan pola pikirnya yang dituangkan baik secara lisan maupun tulisan. Informasi, ide, dan inspirasi tersebut dapat diperoleh melalui keterampilan menyimak.

Tarigan menyatakan bahwa menyimak merupakan suatu proses kegiatan mendengarkan lambang lisan dengan penuh perhatian, pemahaman, apresiasi, serta interpretasi untuk memperoleh informasi, menangkap isi atau pesan serta memahami makna komunikasi yang telah disampaikan oleh sang pembicara melalui ujaran atau bahasa lisan. ${ }^{2}$ Sumber keterampilan menyimak dapat diperoleh dari radio, televisi, ceramah, pidato, wawancara, diskusi, obrolan, maupun peristiwa yang sedang dilihat (terjadi). ${ }^{3}$

${ }^{2}$ Hendry Guntur Tarigan, Menyimak sebagai Suatu Keterampilan Berbahasa (Bandung: Angkasa, 1994), p. 28.

${ }^{3}$ Suparno and Yunus, Keterampilan Dasar Menulis (Jakarta: Universitas Terbuka, 2008), p. 1.5. 
Berikut ini adalah keterampilan-keterampilan mikro yang terlibat ketika kita berupaya untuk memahami apa yang kita dengar, yaitu pendengar harus: ${ }^{4}$

1. menyimpan/mengingat unsur bahasa yang didengar menggunakan daya ingat jangka pendek (short-term memory);

2. berupaya membedakan bunyi-bunyi yang membedakan arti dalam bahasa target;

3. menyadari adanya bentuk-bentuk tekanan dan nada, warna suara dan intonasi; menyadari adanya reduksi bentuk-bentuk kata;

4. membedakan dan memahami arti kata-kata yang didengar;

5. mengenal bentuk-bentuk kata yang khusus (typical word-order patterns);

6. mendeteksi kata-kata kunci yang mengidentifikasikan topik dan gagasan;

7. menebak makna dari konteks;

8. mengenal kelas-kelas kata (grammatical word classes);

9. menyadari bentuk-bentuk dasar sintaksis;

10. mengenal perangkat-perangkat kohesif (recognize cohesive devices);

11. mendeteksi unsur-unsur kalimat seperti subjek, predikat, objek, preposisi, dan unsurunsur lainnya.

Keterampilan berbicara merupakan keterampilan berbahasa yang bersifat produktif, artinya pembicara berperan sebagai penyampai atau pengirim pesan kepada orang lain, yang disampaikan secara lisan. ${ }^{5}$ Eska menyatakan bahwa "Berbicara merupakan suatu keterampilan, dan keterampilan tidak akan berkembang kalau tidak dilatih secara terus menerus. Oleh karena itu, kepandaian berbicara tidak akan dikuasai dengan baik tanpa dilatih". 6

Berikut ini beberapa keterampilan mikro yang harus dimiliki oleh si pembicara dalam melakukan aktivitas berbicara, antara lain: ${ }^{7}$

1. mengucapkan bunyi-bunyi yang berbeda secara jelas sehingga pendengar dapat membedakannya;

4 Yeti Mulyati, "Modul Keterampilan Berbahasa Indonesia SD", file:///C:/Users/USER/Videos/buku\%20UT\%20keterampilan\%20berbahsa.pdf, p. 1.11, accessed on April 2, 2018.

5 Dalman, Keterampilan Menulis (Jakarta: PT RajaGrafindo Persada, 2014), p. 11.

${ }^{6}$ Wirnita Eska, Terampil Berbahasa Indonesia Di Sekolah Dasar (Padang: Bung Hatta University Press, 2011), p. 46.

7 Yeti Mulyati, “Modul, p, 1.12. 
2. menggunakan tekanan, nada, serta intonasi secara jelas dan tepat sehingga pendengar dapat memahami apa yang diucapkan pembicara;

3. menggunakan bentuk-bentuk kata, urutan kata, serta pilihan kata yang tepat;

4. menggunakan register atau ragam bahasa yang sesuai dengan situasi komunikasi dan pelaku komunikasi (hubungan antara pembicara dan pendengar);

5. menyampaikan kalimat-kalimat utama (the main sentence constituents) dengan jelas bagi pendengar;

6. berupaya mengemukakan ide-ide atau informasi tambahan guna menjelaskan ide-ide utama;

7. berupaya agar wacana berpautan secara serasi sehingga pendengar mudah mengikuti pembicaraan.

Kridalaksana menjelaskan membaca adalah keterampilan mengenal dan memahami tulisan dalam bentuk urutan lambang-lambang grafis dan perubahannya menjadi bicara bermakna dalam bentuk pemahaman diam-diam atau pengujaran keraskeras. Kegiatan membaca dapat bersuara nyaring dan dapat pula tidak bersuara (dalam hati). ${ }^{8}$

Keterampilan membaca dan menulis sangat berkaitan erat. Membaca dan menulis merupakan suatu kegiatan yang menjadikan penulis sebagai pembaca dan pembaca sebagai penulis. Seseorang akan mampu menulis setelah membaca karya orang lain atau secara tidak langsung akan membaca karyanya sendiri. Maka dari itu, ia akan berperan juga sebagai penulis. Ia akan menemukan topik dan tujuan, gagasan, serta mengorganisasikan bacaan dari karangan yang dibaca. ${ }^{9}$

Keterampilan-keterampilan mikro yang terkait dengan proses membaca yang harus dimiliki, adalah ${ }^{10}$

1. mengenal sistem tulisan yang digunakan;

2. mengenal kosakata;

3. menentukan kata-kata kunci yang mengidentifikasikan topik dan gagasan utama;

4. menentukan makna kata-kata, termasuk kosakata, dari konteks tertulis;

5. mengenal kelas kata gramatikal: kata benda, kata sifat, dan sebagainya;

\footnotetext{
${ }^{8}$ Dalman, Keterampilan, p. 9.

${ }^{9}$ Suparno and Yunus, Keterampilan, pp. 1.4-1.5.

10 Yeti Mulyati, "Modul, pp. 1.13-1.14.
} 
6. menentukan konstituen-konstituen dalam kalimat, seperti subjek, predikat, objek, dan preposisi;

7. mengenal bentuk-bentuk dasar sintaksis;

8. merekonstruksi dan menyimpulkan situasi, tujuan-tujuan, dan partisipan;

9. menggunakan perangkat kohesif leksikal dan gramatikal guna menarik kesimpulankesimpulan;

10. menggunakan pengetahuan dan perangkat-perangkat kohesif leksikal dan gramatikal untuk memahami topik utama atau informasi utama;

11. membedakan ide utama dari detail-detail yang disajikan;

12. menggunakan strategi membaca yang berbeda terhadap tujuan-tujuan membaca yang berbeda, seperti skimming untuk mencari ide-ide utama atau melakukan studi secara mendalam.

Menulis adalah suatu kegiatan penyampaian pesan (komunikasi) dengan menggunakan bahasa tulis sebagai alat atau medianya. ${ }^{11}$ Menurut Tarigan, menulis ialah menurunkan atau melukiskan lambang-lambang grafis yang menghasilkan suatu bahasa yang dipahami oleh seseorang sehingga orang lain dapat membaca lambang-lambang grafis tersebut dan dapat memahami bahasa dan grafis itu. ${ }^{12}$

Berikut ini keterampilan-keterampilan mikro yang diperlukan dalam menulis, di mana penulis perlu untuk: 13

1. menggunakan ortografi dengan benar, termasuk di sini penggunaan ejaan;

2. memilih kata yang tepat;

3. menggunakan bentuk kata dengan benar;

4. mengurutkan kata-kata dengan benar;

5. menggunakan struktur kalimat yang tepat dan jelas bagi pembaca;

6. memilih genre tulisan yang tepat, sesuai dengan pembaca yang dituju;

7. mengupayakan ide-ide atau informasi utama didukung secara jelas oleh ide-ide atau informasi tambahan;

8. mengupayakan, terciptanya paragraf, dan keseluruhan tulisan koheren sehingga pembaca mudah mengikuti jalan pikiran atau informasi yang disajikan;

11 Suparno and Yunus, Keterampilan, p. 1.3.

21.

12 Hendry Guntur Tarigan, Menulis sebagai Keterampilan Berbahasa (Bandung: Angkasa, 2005), p.

13 Yeti Mulyati, “Modul, pp. $1.14-1.15$. 
9. membuat dugaan seberapa banyak pengetahuan yang dimiliki oleh pembaca sasaran mengenai subjek yang ditulis dan membuat asumsi mengenai hal-hal yang belum mereka ketahui dan penting untuk ditulis.

\section{Teknik Reportase}

Teknik reportase adalah cara mencari, menemukan, atau mengumpulkan bahan berita (news gathering/collecting). ${ }^{14}$ Ada tiga tahap dalam reportase yaitu reportase dasar, reportase madya, dan reportase lanjutan. Diibaratkan seperti rumah, semua teknik reportase dasar mutlak perlu dipakai dalam reportase madya dan reportase lanjutan. Sebaliknya, banyak teknik-teknik dalam reportase lanjutan yang tidak perlu dipakai dalam reportase madya dan reportase dasar. ${ }^{15}$

Seseorang yang melakukan peliputan dan reportase disebut reporter. Seorang reporter dalam menjalankan tugasnya terutama dalam melakukan reportase berita menggunakan teknik berikut ini: Pertama, observasi yaitu terjun langsung ke lokasi peristiwa dengan tujuan reporter dapat melihat langsung kejadian/peristiwa, sehingga berita yang disampaikan tersebut nyata dan konkrit. Kedua, riset data, melalui riset data seorang reporter dapat melihat arsip data dan fakta peristiwa yang sedang terjadi, sehingga akan menjadi sumber utama dalam memberikan dan menyampaikan berita yang akurat. Ketiga, wawancara yaitu menggali informasi dari narasumber yang terkait dengan berita yang akan dibuat sesuai dengan peristiwa yang terjadi. Kegiatan observasi, riset data peristiwa, dan wawancara, mempunyai tujuan utama yaitu untuk mengumpulkan setidaknya data-data yang terdiri dari 5W+1H, yaitu What: Peristiwa apa yang sedang terjadi?, Who : Siapa yang terlibat dalam peristiwa tersebut?, When: Kapan terjadi peristiwa tersebut?, Where: dimanakah peristiwa tersebut terjadi?, Why: Mengapa peristiwa tersebut terjadi?. Keempat, yaitu menyampaikan hasil reportase secara langsung melalui praktik reportase.

Dalam jurnalisme penyiaran televisi, reportase yang paling memiliki eksklusivitas adalah laporan langsung (live report). Format reportase seperti ini dikenal dengan nama live on cam. Reportase secara langsung membutuhkan persiapan yang matang dan

\footnotetext{
14 Husni, Teknik Reportase dan Wawancara, http://misterhusni.com/wpcontent/uploads/2017/09/Teknik-Reportase-dan-Wawancara.pdf, accessed on April 20, 2018. 6.

${ }_{15}$ Parakitri T. Simbolon, Vademekum Wartawan: Reportase Dasar (Jakarta: PT. Gramedia, 2006) p.
} 
peralatan yang mahal. Gambar dan suara yang ditransmisikan melalui kabel ke seperangkat peralatan yang disebut sebagai Satellite News Gathering (SNG) yang berada pada sebuah truk. Dari SNG kemudian dikirim ke satelit menuju studio stasiun televisi untuk dipancarkan ke khalayak. Tentunya dalam reportase secara langsung, kompetensi reporter untuk tampil di depan kamera benar-benar diuji. Sedikit kesalahan akan berakibat fatal, karena tidak ada lagi proses editing. Untuk itu, sebelum melakukan reportase langsung, seorang reporter harus menguasai materi berita yang akan disampaikan melalui reportase. ${ }^{16}$

Agar dapat menyampaikan berita reportase dengan baik, seorang reporter harus mengetahui prinsip-prinsip penulisan berita yang jelas, yaitu sebagai berikut. ${ }^{17}$

1. menggunakan kalimat pendek;

2. mengutamakan kesederhanaan dan menghindari kompleksitas;

3. menggunakan kata-kata yang sudah dikenal serta sesuai dengan kaidah bahasa yang baik dan benar;

4. menghindari kata-kata yang tidak perlu;

5. menggunakan kalimat aktif;

6. ditulis seperti layaknya orang berbicara;

7. menggunakan istilah/terminologi yang bisa dipahami khalayak;

8. dikaitkan dengan pengalaman khalayak;

9. menggunakan bahasa yang variatif.

\section{Metode Penelitian}

Jenis penelitian ini adalah penelitian tindakan kelas (PTK). Menurut Trianto penelitian ini berorientasi pada penerapan tindakan dengan tujuan meningkatkan mutu atau pemecahan masalah pada sekelompok subjek yang diteliti. Dalam penelitian ini juga akan diamati tingkat keberhasilan atau akibat tindakannya, dan pada akhirnya akan diberikan tindakan atau penyesuaian sehingga nantinya diperoleh hasil yang lebih baik. ${ }^{18}$

16 Reportase langsung dapat dilakukan dengan berbagai cara, seperti reporter yang berada di lokasi peristiwa di wawancarai oleh presenter yang ada di studio secara langsung, reporter melakukan wawancara dengan narasumber langsung dari lokasi peristiwa, reporter melaporkan apa yang terjadi di lokasi. Lihat Fajar Junaedi, Jurnalisme Penyaiaran dan Reportase Televisi (Jakarta: Prenadamedia Group, 2013), pp. 23-24.

17 Ibid., p. 19.

18 Trianto, Panduan Lengkap Penelitian Tindakan Kelas (Jakarta: Prestasi Pustaka, 2011), pp. 13-4. 
Rancangan dalam PTK terdiri dari tiga siklus yang mana dalam setiap siklusnya terdapat empat komponen, yaitu perencanaan, pelaksanaan tindakan, hasil tindakan, dan refleksi.

Menurut Lewis, langkah-langkah dalam penelitian PTK yaitu mengidentifikasi gagasan/permasalahan umum, melakukan pengecekan di lapangan, membuat perencanaan umum, mengembangkan tindakan pertama, mengimplementasikan tindakan pertama, mengevaluasi, merevisi perencanaan untuk tindakan kedua, dst. ${ }^{19}$

Menurut Wardhani, prosedur penelitian dalam PTK dilaksanakan dengan menggunakan siklus-siklus tindakan (daur ulang). Daur ulang dalam penelitian diawali dengan perencanaan (planning), tindakan (action), mengobservasi (observation), dan melakukan refleksi (reflecting), hal ini dilakukan berulang - ulang sampai peningkatan yang diharapkan tercapai. ${ }^{20}$

Ada beberapa model Penelitian Tindakan Kelas yaitu model Elliot dengan modifikasi dan model penelitian tindakan kelas Ebbut. ${ }^{21}$ Dalam penelitian ini peneliti menggunakan model Elliot dengan modifikasi, dengan tahap penelitian sebagai berikut: ${ }^{22}$

1. mengidentifikasi masalah;

2. mengecek keadaan lapangan (reconnaissance);

3. perencanaan (langkah/tindakan 1, langkah/tindakan 2, dan langkah/tindakan 3);

4. pelaksanaan (Siklus 1/langkah 1);

5. observasi/pengaruh;

6. reconnaissance diskusi kegagalan \& pengaruhnya refleksi;

7. revisi perencanaan siklus/langkah 2 dan 3.

Penelitian ini merupakan hasil pembelajaran dari mata kuliah Wacana Bahasa Indonesia untuk KPI. Salah satu materi ajar dalam mata kuliah ini adalah praktik reportase. Materi ajar praktik reportase bertujuan melatih keterampilan berbahasa (menyimak, berbicara, membaca, menulis) mahasiswa. Adapun subjek dalam penelitian ini adalah mahasiswa Semester VI Program Studi Komunikasi dan Penyiaran Islam (KPI),

19 J. Elliot, Action Research for Educational Change (Philadelphia: Milton Keynes, 1991), p. 69.

${ }^{20}$ Agil Beti Elviana, "Peningkatan Aktivitas dan Keterampilan Berbicara Melalui Penggunaan Media Gambar Pada Siswa Kelas IV A SDN 1 Tempuran Trimurjo Lampung Tengah", http://download.portalgaruda.org/article.php?article=288756\&val=7239\&title, accesed on April 2, 2018.

21 Syamsuddin, et al., Metode Penelitian Pendidikan Bahasa (Bandung: PT Remaja Rosdakarya Offset, 2007), pp. 230-3.

22 Ibid., p. 231. 
Jurusan Dakwah dan Komunikasi, IAIN Syaikh Abdurrahman Siddik Bangka Belitung Tahun Akademik 2017/2018 yang berjumlah 9 mahasiswa.

Sebelum menerapkan pembelajaran keterampilan berbahasa, Dosen sekaligus peneliti melakukan tes awal berbahasa lisan dengan melakukan praktik reportase langsung di dalam kelas. Kegiatan praktik ini sangat memungkinkan dikarenakan mahasiswa semester VI sudah mendapatkan pembelajaran tentang teori reportase pada semester sebelumnya. Tes awal berbahasa lisan dan tulisan dalam reportase ini bertujuan untuk mengetahui kesiapan belajar dan kemampuan awal mahasiswa yang mana nantinya akan menentukan kesiapan proses belajar-mengajar yang akan diterapkan pada siklus I.

Dalam menganalisis data penelitian ini, peneliti menggunakan metode analisis deskriptif kualitatif dan deskriptif kuantitatif. Adapun langkah-langkah yang peneliti lakukan dalam PTK ini adalah:

1. melakukan prasurvei dan observasi terhadap keadaan dan kemampuan berbahasa lisan mahasiswa yang akan diteliti;

2. mendiagnosis dugaan sementara timbulnya permasalahan;

3. mencari gagasan dalam upaya yang dapat ditempuh dalam memecahkan permasalahan;

4. menentukan perencanaan yang berkaitan dengan rancangan siklus per-siklus;

5. mempersiapkan dan mengimplementasikan strategi dan media yang akan digunakan serta materi yang akan disampaikan;

6. melakukan pengamatan dan monitoring yang dilakukan oleh dosen sekaligus peneliti. Peneliti melakukan monitoring selama kegiatan pembelajaran berlangsung. Hal ini dilakukan untuk mengenali dan mengevaluasi perkembangan yang terjadi akibat tindakan yang telah dilakukan. Teknik yang peneliti lakukan adalah melalui pengamatan, tes, catatan lapangan;

7. melakukan refleksi yaitu berupa rangkaian evaluasi yang dilakukan oleh peneliti yang selanjutnya melalui kegiatan refleksi ini kemudian akan dilakukan perbaikan tindakan pada siklus selanjutnya (hingga siklus ketiga).

\section{E. Hasil Penelitian}


Dalam melaksanakan siklus per siklus, dosen sekaligus peneliti melakukan tahaptahap sebagai berikut:

1. menyusun satuan acara perkuliahan (SAP);

2. membagi kelompok mahasiswa menjadi 3 kelompok. Masing-masing kelompok terdiri dari 3 orang mahasiswa;

3. membimbing mahasiswa menyusun bahan/kerangka reportase. Pada tahap ini mahasiswa menggunakan keterampilan menyimak untuk memahami penyampaian dosen dan keterampilan membaca untuk memahami materi dari bahan bacaan yang diberikan dosen;

4. mahasiswa diterjunkan ke lapangan. Pada tahap ini mahasiswa menggunakan keterampilan menyimak peristiwa yang sedang terjadi secara langsung di objek/lokasi reportase untuk memperoleh ide, inspirasi, maupun informasi yang digali langsung di lokasi reportase;

5. mahasiswa berdiskusi menyusun/merumuskan ide dan objek reportase serta menentukan dan mengamati peristiwa apa yang secara langsung akan dilaporkan. Pada tahap ini, mahasiswa menggunakan keterampilan menyimak dan berbicara untuk saling berdiskusi dan bertukar pikiran;

6. mahasiswa menyiapkan peralatan yang diperlukan, seperti buku catatan, pena, cam recorder, microphone, dan lain-lain;

7. masing-masing mahasiswa dalam kelompok berperan sebagai wartawan, warga yang diwawancarai, dan cameramen.

8. mahasiswa merumuskan pertanyaan menggunakan rumus $5 \mathrm{~W}+1 \mathrm{H}$ untuk mengembangkan dan menarasikan objek reportase;

9. ketika sudah siap, mahasiswa pemeran reporter mulai melaporkan peristiwa berlangsung, dan mahasiswa pemeran cameramen siap mendokumentasikan peristiwa dengan cam recorder serta mahasiswa pemeran warga siap untuk diwawancarai;

10. dosen sekaligus peneliti mengamati langsung hasil reportase mahasiswa dan mencatat hal-hal penting yang terjadi;

11. masing-masing kelompok memberikan masukan/kritikan terhadap hasil reportase kelompok lainnya; 
12. dosen memberikan evaluasi dan masukan terhadap kekurangan dari segi aspek kebahasaan, diksi, kelancaran, performance, maupun redaksi reportase;

13. dosen memberikan penguatan-penguatan dan reward kepada kelompok terbaik;

14. karya mahasiswa dalam bentuk video berita reportase dapat ditonton ulang dan dipublikasikan.

Siklus I dilaksanakan pada Tanggal 6 April 2018, dengan Tema: Pembelajaran Outdoor. Pada siklus ini mahasiswa diterjunkan langsung ke Taman Tarbiyah yang sering dimanfaatkan para dosen dan mahasiswa untuk melakukan proses belajar mengajar.

Siklus II dilaksanakan pada Tanggal 13 April 2018 dengan Tema: Acara Kopitehkustik. Pada siklus ini, mahasiswa meliput acara Kopitehkustik yang diselenggarakan oleh Jurusan Dakwah dan Komunikasi bertempat di halaman Taman Tarbiyah.

Siklus III dilaksanakan pada Tanggal 20 April 2018, dengan Tema: Pembangunan Gedung Baru. Pada siklus ini mahasiswa diterjunkan langsung di salah satu Gedung Baru yang sedang dibangun di IAIN Syaikh Abdurrahman Siddik Bangka Belitung.

\section{Hasil Siklus I}

Tabel 1. Hasil Siklus I

Keterampilan Berbahasa Mahasiswa melalui Praktik Reportase

\begin{tabular}{cccc}
\hline \multirow{2}{*}{ No } & \multirow{2}{*}{ Nilai } & \multicolumn{2}{c}{ Siklus I } \\
\cline { 3 - 4 } & & Jumlah & $\%$ \\
\hline 1 & $61-65$ & 1 & 11,11 \\
\hline 2 & $66-70$ & 2 & 22,22 \\
\hline 3 & $71-75$ & 1 & 11,11 \\
\hline 4 & $76-80$ & 3 & 33,33 \\
\hline 5 & $81-85$ & 2 & 22,22 \\
\hline 6 & $86-90$ & - & - \\
\hline 7 & $91-95$ & - & - \\
\hline & Jumlah & 9 & 100 \\
\hline & Nilai rata-rata kelas & \multicolumn{2}{c}{74,66} \\
\hline
\end{tabular}

\section{Hasil Siklus II}

Tabel 2. Hasil Siklus II

Keterampilan Berbahasa Mahasiswa melalui Praktik Reportase

\begin{tabular}{cccc}
\hline \multirow{2}{*}{ No } & \multirow{2}{*}{ Nilai } & \multicolumn{2}{c}{ Siklus II } \\
\cline { 3 - 4 } & & Jumlah & $\%$ \\
\hline 1 & $61-65$ & - & - \\
\hline 2 & $66-70$ & 1 & 11,11 \\
\hline
\end{tabular}




\begin{tabular}{cccc}
\hline \multirow{2}{*}{ No } & \multirow{2}{*}{ Nilai } & \multicolumn{2}{c}{ Siklus II } \\
\cline { 3 - 4 } & & Jumlah & $\%$ \\
\hline 3 & $71-75$ & 2 & 22,22 \\
\hline 4 & $76-80$ & 2 & 22,22 \\
\hline 5 & $81-85$ & 2 & 22,22 \\
\hline 6 & $86-90$ & 1 & 11,11 \\
\hline 7 & $91-95$ & 1 & 11,11 \\
\hline & Jumlah & 9 & 100 \\
\hline & Nilai rata-rata kelas & \multicolumn{2}{c}{79,66} \\
\hline
\end{tabular}

\section{Hasil Siklus III}

Tabel 3. Hasil Siklus III

Keterampilan Berbahasa Mahasiswa melalui Praktik Reportase

\begin{tabular}{cccc}
\hline \multirow{2}{*}{ No } & \multirow{2}{*}{ Nilai } & \multicolumn{2}{c}{ Siklus II } \\
\cline { 3 - 4 } & & Jumlah & $\%$ \\
\hline 1 & $61-65$ & - & - \\
\hline 2 & $66-70$ & - & - \\
\hline 3 & $71-75$ & 1 & 11,11 \\
\hline 4 & $76-80$ & 1 & 11,11 \\
\hline 5 & $81-85$ & 1 & 11,11 \\
\hline 6 & $86-90$ & 4 & 44,44 \\
\hline 7 & $91-95$ & 2 & 22,22 \\
\hline \multicolumn{2}{r}{ Nilai rata-rata kelas } & \multicolumn{2}{c}{85,77} \\
\hline
\end{tabular}

\section{Hasil Peningkatan Nilai Rata-rata Kelas Persiklus}

Grafik 1. Rekapitulasi Peningkatan Nilai Rata-rata Kelas Persiklus

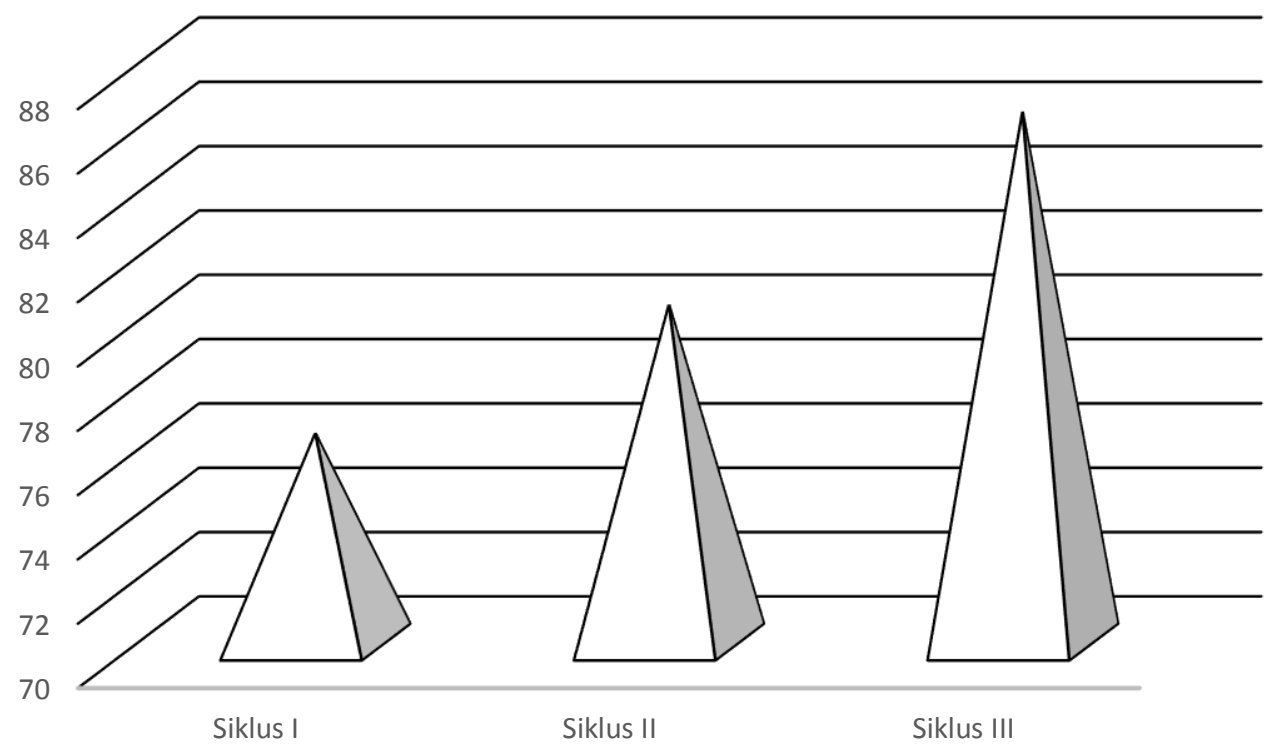




\section{F. Pembahasan}

\section{Siklus I}

Pada siklus I, mahasiswa yang memperoleh retang nilai 61 - 65 sebanyak 1 orang dengan presentase 11,11\%. Rentang nilai 66 - 70 sebanyak 2 orang mahasiswa dengan presentase 22,22\%. Rentang nilai 71 - 75 sebanyak 1 orang mahasiswa dengan presentase 11,11\%. Rentang nilai 76 - 80 sebanyak 3 orang mahasiswa dengan presentase 33,33\% dan rentang nilai 81 - 85 sebanyak 2 orang mahasiswa dengan presentase $22,22 \%$.

Pada siklus I terlihat bahwa nilai rata-rata perkelas diperoleh 74,66. Maka keterampilan berbahasa (menyimak, berbicara, membaca, menulis) mahasiswa dikatakan cukup baik.

\section{Siklus II}

Pada siklus II, mahasiswa yang memperoleh rentang nilai 66 - 70 sebanyak 1 orang, dengan presentase 11,11\%. Mahasiswa yang memperoleh rentang nilai 71 - 75 sebanyak 2 orang, dengan presentase 22,22\%. Rentang nilai 76 - 80 sebanyak 2 orang, dengan presentase 22,22\%. Rentang nilai 81 - 85 sebanyak 2 orang, dengan presentase 22,22\%. Rentang nilai antara 86 - 90 sebanyak 1 orang mahasiswa, dengan presentase 11,11\% dan rentang nilai 91 - 95 sebanyak 1 orang mahasiswa, dengan presentase $11,11 \%$.

Dari siklus II, keterampilan berbahasa mahasiswa mengalami sedikit peningkatan. Hal ini terlihat dari nilai rata-rata kelas yaitu meningkat menjadi 79,66. Pada siklus II keterampilan berbahasa mahasiswa masih dalam kategori cukup baik. Keterampilan berbahasa mahasiswa ada siklus II mengalami perkembangan meskipun tidak terlalu tinggi. Adapun peningkatan nilai rata-rata kelas dari siklus I ke siklus II yaitu 5,00.

\section{Siklus III}

Pada siklus III, mahasiswa yang memperoleh rentang nilai 71 - 75 sebanyak 1 orang, dengan presentase 11,11\%. Mahasiswa yang memperoleh rentang nilai antara 76 - 80 sebanyak 1 orang, dengan presentase 11,11\%. Rentang nilai antara 81 - 85 sebanyak 1 orang, dengan presentase 11,11\%. Rentang nilai antara 86 - 90 sebanyak 4 orang mahasiswa, dengan presentase 44,44\% dan rentang nilai antara 91 - 95 sebanyak 2 orang mahasiswa, dengan presentase $22,22 \%$. 
Pada siklus III terjadi peningkatan yang cukup signifikan dengan nilai rata-rata kelas 85,77 . Keterampilan berbahasa pada siklus III dapat dikategorikan baik. Adapun peningkatan nilai rata-rata kelas dari siklus II ke siklus III yaitu sebesar 6,11.

\section{G. Penutup}

Keterampilan berbahasa meliputi empat aspek yaitu keterampilan menyimak (listening skills), keterampilan berbicara (speaking skills), keterampilan membaca (reading skills), dan keterampilan menulis (writing skills). Keempat aspek keterampilan berbahasa tersebut saling berkaitan satu sama lain. Dalam meningkatkan keterampilan berbahasa untuk mahasiswa Program studi Komunikasi dan Penyiaran islam (KPI) pada mata kuliah Wacana Bahasa Indonesia untuk KPI, dapat dilakukan melalui praktik reportase dengan didasarkan pada teknik-teknik reportase yaitu observasi, riset data, wawancara, dan menyampaikan hasil reportase secara langsung melalui kegiatan praktik reportase.

Pada siklus I terlihat bahwa nilai rata-rata perkelas diperoleh 74,66. Maka keterampilan berbahasa (menyimak, berbicara, membaca, menulis) mahasiswa Program Studi KPI dapat dikatakan cukup baik. Siklus II menunjukkan bahwa, keterampilan berbahasa mahasiswa mengalami sedikit peningkatan. Hal ini terlihat dari nilai rata-rata kelas yaitu meningkat menjadi 79,66. Pada siklus II keterampilan berbahasa mahasiswa masih dalam kategori cukup baik. Keterampilan berbahasa mahasiswa pada siklus II mengalami perkembangan meskipun tidak terlalu tinggi. Adapun peningkatan nilai ratarata kelas dari siklus I ke siklus II yaitu 5,00. Pada siklus III terjadi peningkatan yang cukup signifikan dengan nilai rata-rata kelas 85,77. Keterampilan berbahasa pada siklus III dapat dikategorikan baik. Adapun peningkatan nilai rata-rata kelas dari siklus II ke siklus III yaitu sebesar 6,11. 


\section{DAFTAR PUSTAKA}

Dalman, Keterampilan Menulis, Jakarta: PT RajaGrafindo Persada, 2014.

Elliot, J., Action Research for Educational Change, Philadelphia: Milton Keynes, 1991.

Elviana, Agil Beti, Peningkatan Aktivitas dan Keterampilan Berbicara Melalui Penggunaan Media Gambar Pada Siswa Kelas IV A SDN 1 Tempuran Trimurjo Lampung Tengah[http://download.portalgaruda.org/article.php?article $=288756 \&$ val $=72$ 39\&title], accesed on April 2, 2018.

Eska, Wirnita, Terampil Berbahasa Indonesia Di Sekolah Dasar, Padang: Bung Hatta University Press, 2011.

Husni, Teknik Reportase dan Wawancara http://misterhusni.com/ wpcontent/ uploads/ 2017/09/Teknik-Reportase-dan-Wawancara.pdf. accesed on June 20, 2018.

Junaedi, Fajar, Jurnalisme Penyaiaran dan Reportase Televisi, Jakarta: Prenadamedia Group, 2013.

Mafrukhi, et al., Bagaimana Meningkatkan Kemampuan Membaca, Jakarta: Erlangga, 2007.

Mulyati, Yeti. Modul Keterampilan Berbahasa Indonesia SD. file: ///C:/Users/ USER/Videos/buku\%20UT\%20keterampilan\%20berbahsa.pdf. accessed on April 2, 2018.

Simbolon, Parakitri T., Vademekum Wartawan: Reportase Dasar, Jakarta: PT. Gramedia, 2006.

Suparno and Yunus, Keterampilan Dasar Menulis, Jakarta: Universitas Terbuka, 2008.

Syamsuddin, et al., Metode Penelitian Pendidikan Bahasa, Bandung: PT Remaja Rosdakarya Offset, 2007.

Tarigan, Hendry Guntur, Menulis sebagai Keterampilan Berbahasa, Bandung: Angkasa, 2005.

----, Menyimak sebagai Suatu Keterampilan Berbahasa, Bandung: Angkasa, 1994.

Trianto, Panduan Lengkap Penelitian Tindakan Kelas, Jakarta: Prestasi Pustaka, 2011. 